UDC 616-006.487.48-039.36-037-053.2: 575.24

\title{
MiR-137 expression in neuroblastoma: a role in clinical course and outcome
}

\author{
M. V. Inomistova ${ }^{1,2}$, N. M. Khranovska ${ }^{1}$, O. V. Skachkova ${ }^{1}$, \\ G. I. Klymniuk ${ }^{1}$, S. V. Demydov², N. M. Svergun ${ }^{1}$ \\ ${ }^{1}$ National Cancer Institute \\ 33/43, Lomonosova Str., Kyiv, Ukraine, 03022 \\ ${ }^{2}$ ESC "Institute of Biology", Taras Shevchenko National University of Kyiv \\ 64/13, Volodymyrska Str., Kyiv, Ukraine, 01601 \\ m.inomistova@gmail.com
}

\begin{abstract}
Aim. To investigate association of the miR-137 expression in neuroblastoma patients with clinical and biological characteristics of the tumor, and the relationship with survival rates. Methods. qRT-PCR, FISH. Results. Analysis of 61 primary diagnosed neuroblastoma samples revealed a significantly lower expression of miR-137 in patients with the higher risk prognostic factors including the MYCN amplification, onset age, disease stage and overexpression of he 553 antagonist MDM2. Although miR-137 is not an independent risk factor, its higher expression was significantly associated with both improved event-free survival (5 year: $50.4 \%$ vs. $12.2 \%$ ) and overall survival ( 5 year: $46.9 \%$ vs. $19.1 \%$ ), indicating a potential tumor suppressor role in neuroblastoma. Conclusion. We identified miR-137 as a new microRNA of potential importance for the neuroblastoma tumor biology. We demonstrated that miR-137 expression can be used as a biomarker to stratify the neuroblastoma patients according to the clinical course.
\end{abstract}

Key w or d s: neuroblastoma, miR-137 expression

\section{Introduction}

Neuroblastoma (NB) is the most common pediatric solid tumor and represents $15 \%$ of all childhood cancer deaths [1]. It is a neuroendocrine tumor, arising from any neural crest element of the sympathetic nervous system [2]. Remarkable heterogeneity is observed in the tumor phenotype, ranging from spontaneous regression to relentless progression. NBs are heterogeneous in terms of both genotype and clinical behavior. Recent studies have suggested that these two features are related, and that the genotype frequently is predictive of the response to treatment or the patient outcome [3].

NB remains a significant challenge as high-risk patients are treated with intensive multimodal the- rapies but cure rates are still suboptimal. The dozens of clinical and biologic markers have been proposed as being predictive of disease outcome, but many clinical correlative studies are focused on the identification of the markers, which can be used in clinics to optimize the therapy for an individual patient [4].

The aberrant expression of microRNAs has recently been reported in many tumors, including NB. MicroRNAs are small non-coding RNAs derived from the longer precursors that regulate $30 \%$ of the human gene expression at the posttranscriptional level by targeting messenger RNAs (mRNAs) [1]. In cancer, the function of microRNAs is dependent on their mRNA targets, so they can act as tumor suppressors or as oncogenes [5].

(C) 2016 M. V. Inomistova et al.; Published by the Institute of Molecular Biology and Genetics, NAS of Ukraine on behalf of Biopolymers and Cell. This is an Open Access article distributed under the terms of the Creative Commons Attribution License (http://creativecommons.org/licenses/by/4.0/), which permits unrestricted reuse, distribution, and reproduction in any medium, provided the original work is properly cited 
MicroRNAs regulate multiple steps of neurogenesis. Neurogenesis includes self-renewal and fate specification of neural stem cells, migration and maturation of young neurons, and functional integration of new neurons into the neural circuitry. MicroRNAs have been shown to regulate all these steps of neurogenesis by base-pairing with target mRNAs to control the target gene expression [6]. The brain-enriched microRNA, miR-137, plays a significant role in regulating neuronal maturation. Overexpression of miR-137 inhibits the dendritic morphogenesis, phenotypic maturation, and spine development in both brain and cultured primary neurons. On the other hand, a reduction in miR-137 has the opposite effects [7]. MiR-137 may directly or indirectly regulate the expression of other "undifferentiated state" genes in the context of preservation of the proper central nervous system (CNS) development. However, a precise role of this microRNA at the early stages of neuronal differentiation during the embryonic development has not been clearly identified.

MiR-137 is located on chromosome 1p22 and is downregulated in several human cancer types, including the colorectal, bladder, pancreatic, lung cancer, glioblastoma, oral cancer and head and neck squamous cell carcinoma, and many others [8]. Furthermore, the miR-137 overexpression in NB cell lines reduces the cell viability and proliferation while promoting the neuronal differentiation. Also, miR-137 functions as a tumor suppressor in NB by downregulating histone demethylase, KDM1A, which represses the p53/TP53-mediated transcriptional activation [9]. In recent studies, an inducing effect of miR-137 on p53 was shown in different cancer and normal cell lines [9-12]. MiR-137 targets KDM1A mRNA for degradation and leads to a consequent release of p53 from the KDM1A suppression which causes the p53 mediated cellular senescence [12].

The p53/MDM2 pathway is often inactivated in NB by different mechanisms and is involved in the $M Y C N$ oncogene overexpression, which plays a critical role in determining the clinical behavior of
NB [13]. MDM2 has been recently characterized in $\mathrm{NB}$ cell lines as a transcriptional target of MYCN [14]. MYCN also transcriptionally upregulates the p53 expression in NB and may be an important mechanism by which MYCN induces apoptosis [15]. However, no evidence of a direct interaction with MDM2 or MYCN has been reported for miR-137. A number of studies demonstrate the changes in the miR-137 functional activity and expression in NB cells with the MYCN amplification $(M N A)[9,16,17]$.

In this study we investigated an association of the miR-137 expression in the NB patients with clinical and biological characteristics of the tumor and the relationship with survival rates.

\section{Materials and Methods}

\section{Study subject}

61 patients with verified diagnose of NB were enrolled into this study. The age of patients ranged from 1 month to 17 years, mean age was $36.4 \pm 5.6$ months. Stages distribution: I-II stage $20 \%$, III stage $-24 \%$, IV stage $-56 \%$ of patients. All patients were treated in accordance with international standards of treatment for NB. Written informed consent was obtained from patients' parents for tissue sampling according to the requirements of the protocol N 35 from 1.03.2015 approved by Ethical Commission of the National Cancer Institute.

Tumor samples were collected before any cytoreductive treatment by biopsy or tumor resection. $86.9 \%$ of samples were obtained from primary NB tumors, $13.1 \%$ - from recurrent and metastatic foci. Fresh tumor samples for qPCR analysis were stored in "RNA-later" (Ambion, USA) to stabilize RNA and DNA; for fluorescent in situ hybridization (FISH), formalin-fixed, paraffin embedded tissue (FFPE) samples were used.

\section{$q R T-P C R$}

Nucleic acids were extracted from the tumor samples using Nucleo Spin MiRNA (Macherey-Nagel, Germany). Total RNA was reverse transcribed to 
cDNA with stem-loop primers and the TaqMan MicroRNA Reverse Transcription kit (Applied Biosystems, USA). To quantify endogenous miR-137, TaqMan MicroRNA Assays (Applied Biosystems, USA) were used. Level of miR-137 was normalized to U6 snRNA expression. Realtime RT-qPCR was performed with 7500 RealTime PCR System (Applied Biosystems, USA) and TaqMan Universal PCR MasterMix. Calculations were performed using the $\Delta \Delta \mathrm{Ct}$ relative quantification method.

Genomic MYCN status was assessed in NB fresh tumors by real-time qPCR analysis and FISH for FFPE samples. MDM2 mRNA expression level was detected by real-time RT-qPCR using TaqMan primers and probes. $M Y C N$ status and MDM2 expression in NB tumor samples were analyzed, as previously described [18]. Results were normalized to relevant controls.

\section{Statistical analysis}

All experiments were repeated independently at least three times. Gaussian distribution of the group was checked with Kolmogorov-Smirnov tests. Analysis of the association between the studied markers and clinical characteristics of patients was performed using U-Mann-Whitney test. Prognostic significance of markers was verified with the ROCcurve (Receiver Operating Characteristic curve). Event-free and overall survival was evaluated by Kaplan-Meier estimator, statistical significance of parameters differences was determined using F-Cox criterion. The time to event was calculated as the time from study enrollment to the first occurrence of relapse, progressive disease, secondary malignancy or death. Patients without events were censored at the time of last contact. Overall survival time was calculated as the time from study enrollment until the time of death or the time of last contact if the patient was alive. The data were processed with the software package Statistica 6.1 using parametric and nonparametric methods of statistical analysis and MedCalc 12.1.4.0. The difference was considered statistically significant at $\mathrm{p}<0.05$.

\section{Results and Discussion}

In this study we established that the value of miR-137 expression varied quite widely in the NB tumor samples depending on the occurrence age, disease stage, $M Y C N$ gene status and MDM2 expression level, and a lower expression was observed in the patients with known higher-risk prognostic factors. There was a statistically insignificant decrease in the miR-137 expression level in the samples from recurrent and metastatic foci comparing to the primary tumors (Fig. 1A). This may indicate a role of $\mathrm{miR}-137$ in the development and pathogenesis of NB.

We used a Mann-Whitney U-test to identify the microRNA differentially expressed between the tumors with different molecular and clinical features. It is known that the age of patients at the time of the disease detection is an independent prognostic marker of NB prognosis used by different stratification systems [19]. The patients were subdivided by age into patients younger than 12 months, from 12 to 24,24 months and older. Interestingly, miR-137 was differentially expressed between all these age groups. We observed the lowest expression of miR-137 in the patients from 12 to 24 months in the primary tumor samples, $\mathrm{p}<0.02$ (Fig. 1B). This phenomenon still needs further study and explanation.

The stage were defined for the entire NB cohort with regard to the metastatic progression (I-II without metastases, III with regional metastases and IV with distant metastases). We also distinct the groups with different $M Y C N$ status causing a clinically aggressive NB course. The miR-137 expression was lower in the tumor samples obtained from the patients with the disseminated disease stages compared with the early-stages, $p=0.04$ (Fig. 1C) and in the patients with a high MDM2 expression compared with a low one, $\mathrm{p}=0.04$ (Fig. 1E). This testifies to the assumption that this microRNA regulates the $\mathrm{p} 53$-mediated signaling pathway by interaction with MDM2. MicroRNA miR-137 was considerably differentially expressed between MNA and $M Y C N$-negative tumors, 
$\mathrm{p}<0.001$ (Fig. 1D). Our findings confirm MNA as a major cause of differential microRNA expression in NB. The frequency of MNA detected in our study $(32.7 \%)$ did not differ from the data obtained by other research groups [20].

We used ROC-analysis to assess the prognostic significance of the miR-137 expression in the NB progression and outcome. Overall (OS) and eventfree survival (EFS) rates were applied as the criteria of clinical efficacy for patient distribution on groups according to the miR-137 expression level. As follows, a low miR-137 expression was shown as a marker of unfavorable NB and risk of the disease recurrence. This marker has sufficient sensitivity and specificity for both OS (AUC: 0.67, $p=0.03$, Se: $76.9 \%$, Sp: $62.5 \%$, optimal criterion: $\leq 0.06$ a.u.) and EFS (AUC: 0.7, p=0.009, Se: 66.7\%, Sp: 72.7\%, optimal criterion: $\leq 0.04$ a.u.) and may serve as an independent marker of prognosis and stratification of the NB patients on risk groups.

The patients were divided into two groups according to the miR-137 expression level (high and low expression) by the ROC-analysis optimal criterion. As the result, the low miR-137 expression was found in $52.8 \%(28 / 53)$ of patients.

Thus, the low miR-137 expression was associated with the unfavorable clinical NB features (MNA, disease stage, $M D M 2$ expression), indicating a link
$A$

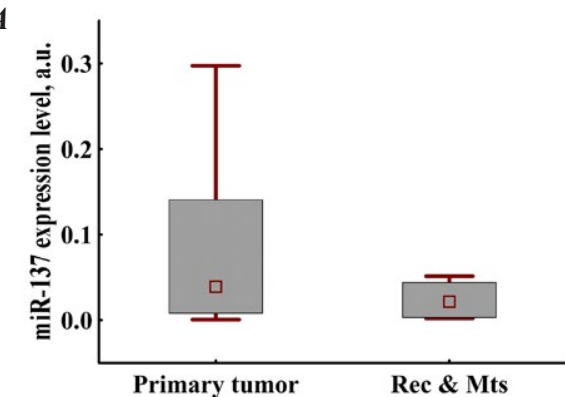

C
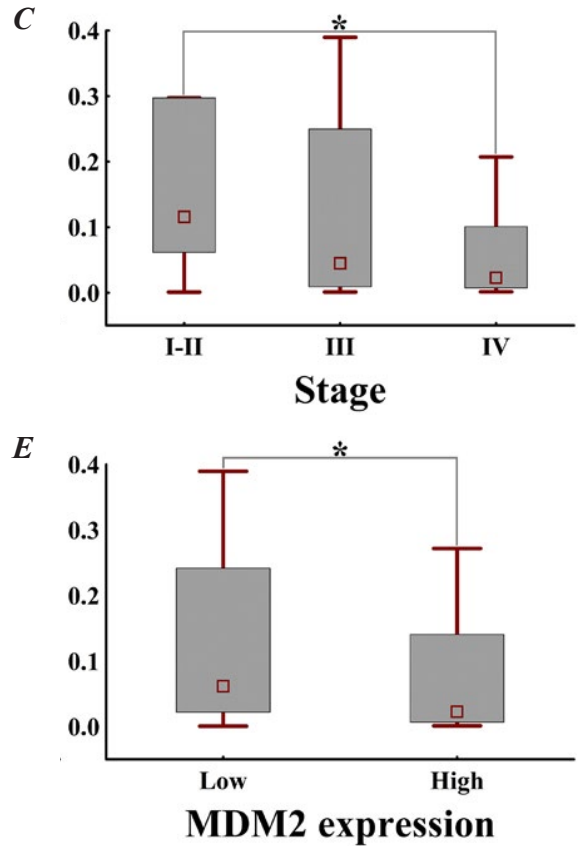

B

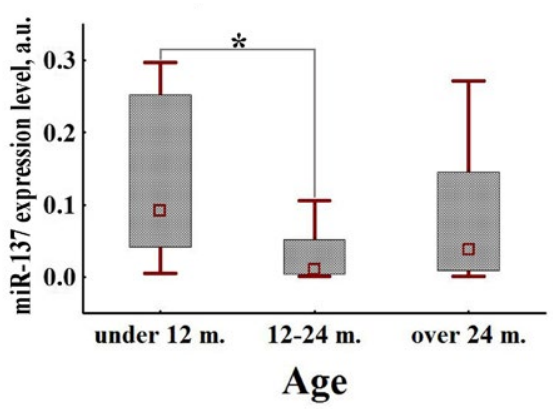

D

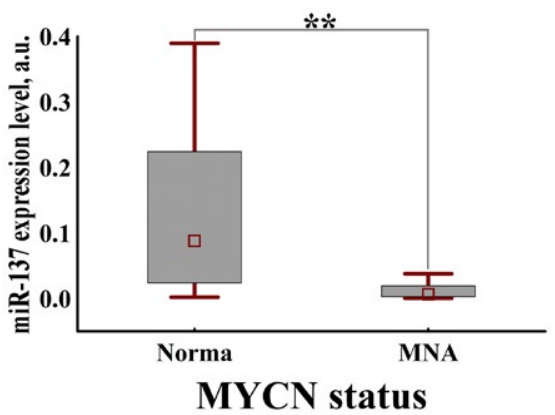

Fig. 1. MiR-137 expression levels in NB tumor samples. $A-\mathrm{miR}$ 137 expression in primary tumors, recurrent and metastatic foci; $B$ miR-137 expression level in primary tumors from NB patients, depending on the occurrence age; $C-\mathrm{miR}-137$ expression in primary tumors of patients with different stages of NB; $D-$ miR-137 expression level in primary tumors with and without MNA; $E-\operatorname{miR}$ 137 expression in primary tumors of patients depending on the level of MDM2 expression. Box plots show miR-137 expression level, a.u., the square represents the median, the box represents the interquartile range, the whiskers represent 5-95 percentile.

Notes: p-Values from Mann-Whitney U-tests of $<0.05(*),<0.001$ $(* *) ;$ m. - months; a.u. - arbitrary units. 

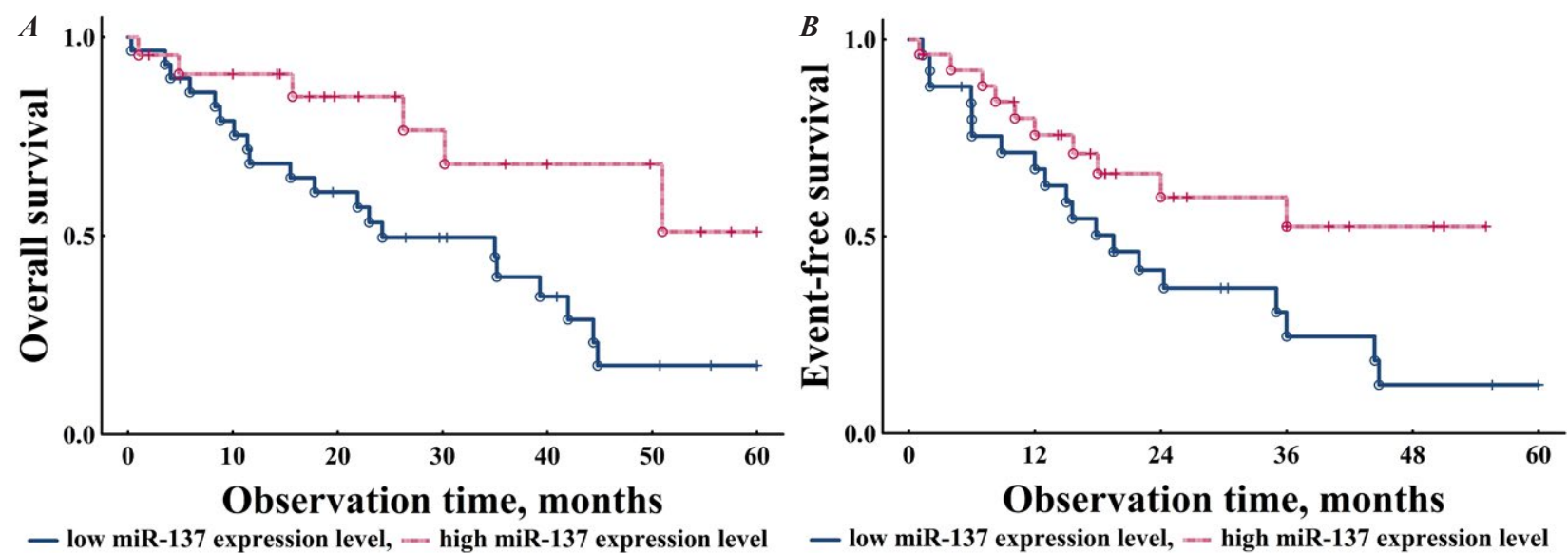

Fig. 2. Kaplan-Meier graphs of OS (A) and EFS (B) for NB patients regarding miR-137 expression level.

between the miR-137 under expression and the highrisk phenotype.

To confirm the obtained results we have analyzed the overall (OS) and event-free survival (EFS) of the NB patients depending on the miR137 expression level. The analysis of the miR-137 expression level in the primary diagnostic neuroblastoma samples revealed a significant association of a low miR-137 expression with poor EFS and OS. We found that the patients with a low miR-137 expression had less favorable EFS $(p<0.01)$ and OS $(p<0.01)$ than the patients with the highly miR-137 expressed tumors $(12.2 \%$ and $19.1 \%$ vs $50.4 \%$ and $46.9 \%$, respectively; Fig. 2). Such a significant difference suggests that this marker can play a substantial role in the pathogenesis and progression of NB.

Therefore, a decreased miR-137 expression was associated with a risk of the disease recurrence and generally with the reduction of patients' lifetime. Such a significant difference suggests that this marker plays a substantial role in the pathogenesis and progression of NB.

Taking into account a strong correlation with major determinants of tumor biology and clinical course, we consider miR-137 as a miRNA of potentially high importance in the NB tumor biology. Our results are in line with the recent report by
Althoff K. et al. [9], who also reported a high miR137 expression to be correlated with a favorable prognosis for the NB patients. To date, little is known about the miR-137 functionality or involvement in the disease. The role of miR-137 in general as well as in the NB tumor biology strongly warrants further investigations. We assume that miR-137 may be an indirect upstream regulator of p53 mostly by the degradation of KDM1A and the violation of its expression in NB is one of the possible mechanisms of the p53 pathway deregulation along with other alterations. The pathways, by which p53 regulates this microRNA, as well as possible interplay with $M Y C N$ and $M D M 2$ remain to be elucidated.

\section{Conclusions}

Taken together, we here demonstrate that the microRNA expression can be used as a biomarker to stratify the NB patients according to the clinical course. We identified that miR-137 is potentially important for the NB tumor biology. The expression of miR-137, which is repressed in the $M Y C N$-amplified tumors, was negatively associated with the $M D M 2$ gene expression and predictive of survival. Further studies are necessary to test a predictive facility of the miRNA-137 expression in a larger number of patients. 


\section{REFERENCES}

1. Schulte JH, Schowe B, Mestdagh P, Kaderali L, Kalaghatgi P, Schlierf S, Vermeulen J, Brockmeyer B, Pajtler $K$, Thor T, de Preter K, Speleman F, Morik K, Eggert A, Vandesompele J, Schramm A. Accurate prediction of neuroblastoma outcome based on miRNA expression profiles. Int $J$ Cancer. 2010;127(10):2374-85.

2. Maris JM, Hogarty MD, Bagatell R, Cohn SL. Neuroblastoma. Lancet. 2007;369(9579):2106-20.

3. Brodeur GM, Nakagawara A. Molecular basis of clinical heterogeneity in neuroblastoma. Am J Pediatr Hematol Oncol. 1992;14(2):111-6.

4. Maris JM. The biologic basis for neuroblastoma heterogeneity and risk stratification. Curr Opin Pediatr. 2005;17(1):7-13.

5. Garzon R, Calin GA, Croce CM. MicroRNAs in Cancer. Annu Rev Med. 2009;60:167-79.

6. Shi Y, Zhao X, Hsieh J, Wichterle H, Impey S, Banerjee $S$, Neveu $P$, Kosik KS. MicroRNA regulation of neural stem cells and neurogenesis. J Neurosci. 2010;30(45):14931-6.

7. Smrt RD, Szulwach KE, Pfeiffer RL, Li X, Guo W, Pathania M, Teng ZQ, Luo Y, Peng J, Bordey A, Jin P, Zhao X. MicroRNA miR-137 regulates neuronal maturation by targeting ubiquitin ligase mind bomb-1. Stem Cells. 2010; 28(6):1060-70.

8. Suzuki H, Yamamoto E, Maruyama R. Epigenetic Regulation of microRNA Genes in Colorectal Cancer. MicroRNA in Development and in the Progression of Cancer. 2014; 199-211.

9. Althoff K, Beckers A, Odersky A, Mestdagh P, Köster J, Bray IM, Bryan K, Vandesompele J, Speleman F, Stallings RL, Schramm A, Eggert A, Sprüssel A, Schulte JH. MiR-137 functions as a tumor suppressor in neuroblastoma by downregulating KDM1A. Int J Cancer. 2013; 133(5):1064-73.

10. Magenta A, Rossini A, Fasanaro P, Pompilio G, Capogrossi MC. MicroRNAs in Cardiac Regeneration, In: Sen CK, Eds MicroRNA in Regenerative Medicine. Elsevier Inc 2015; $917-42$.

11. Lee JM, Cho KW, Kim EJ, Tang Q, Kim KS, Tickle C, Jung HS. A contrasting function for miR-137 in embryonic mammogenesis and adult breast carcinogenesis. Oncotarget. 2015;6(26):22048-59.

12. Neault M, Mallette FA, Richard S. miR-137 Modulates a Tumor Suppressor Network-Inducing Senescence in Pancreatic Cancer Cells. Cell Rep. 2016;14(8):1966-78.

13. Carr-Wilkinson J, O'Toole K, Wood KM, Challen CC, Baker AG, Board JR, Evans L, Cole M, Cheung NK, Boos J, Köhler G, Leuschner I, Pearson AD, Lunec J, Tweddle DA. High frequency of p53/MDM2/p14ARF pathway abnormalities in relapsed neuroblastoma. Clin Cancer Res. 2010;16(4):1108-18.
15. Chen L, Iraci N, Gherardi S, Gamble LD, Wood KM, Perini $G$, Lunec $J$, Tweddle $D A$. p53 is a direct transcriptional target of MYCN in neuroblastoma. Cancer Res. 2010; 70(4):1377-88.

16. Huang M, Weiss WA. Neuroblastoma and MYCN. Cold Spring Harb Perspect Med. 2013;3(10):a014415.

17. Beckers A, Ongenaert M, Decock A, Kumps C, Pattyn F, Neuroblastoma Research Consortium (NRC), Mestdagh P, Schulte J, Speleman F, De Preter K. MiR-137 is epigenetically silenced in MYCN amplified neuroblastomas and targets the polycomb repressive complex 2 (PRC2) component EZH2. Advances in Neuroblastoma Research (Abstracts). Toronto. 2012:id 4432060.

18. Inomistova MV, Svergun NM, Khranovska NM, Skachkova OV, Gorbach OI, Klymnyuk GI. Prognostic significance of MDM2 gene expression in childhood neuroblastoma. Exp Oncol. 2015;37(2):111-5.

19. Evans AE, D'Angio GJ. Age at diagnosis and prognosis in children with neuroblastoma. J Clin Oncol. 2005; 23(27):6443-4.

20. Cohn SL, Pearson AD, London WB, Monclair T, Ambros PF, Brodeur GM, Faldum A, Hero B, Iehara T, Machin D, Mosseri V, Simon T, Garaventa A, Castel V, Matthay KK. INRG Task Force. The International Neuroblastoma Risk Group (INRG) classification system: an INRG Task Force report. J Clin Oncol. 2009;27(2):289-97.

\section{Експресія мікроРНК-137 при нейробластомі: роль в клінічному перебігу захворювання.}

М. В. Іномістова, Н. М. Храновська, О. В. Скачкова, Г. І. Климнюк, С. В. Демидов, Н. М. Свергун

Мета. Дослідити асоціацію експресії мікроРНК-137 у хворих на нейробластому з клінічними та біологічними характеристиками пухлини та зв'язок з виживаністю. Методи. qRT-PCR, FISH. Результати. Аналіз рівнів експресії мікроРНК-137 в 61 зразках первинно діагностованої нейробластоми показав, що у хворих з відомими прогностичними факторами високого ризику, такими як ампліфікація онкогена $M Y C N$, вік на момент виявлення захворювання, IV стадія захворювання і висока експресія $M D M 2$, антагоніста р53 з онкогенними властивостями, рівень експресії мікроРНК-137 значно знижений. Незважаючи на те, що експресія мікроРНК-137 не $є$ незалежним фактором ризику, іiї підвищення в значній мірі пов'язане як з покращенням безрецидивної виживаності (5-ти річна: 50,4 \% проти $12,2 \%$ ), так і загальної виживаності (5-ти річна: 46,9 \% проти 19,1 \%), що вказує на її потенційну роль як онкосупрессора при нейробластомі. Висновки. Ми визначили, що мікроРНК-137 має потенційно важливу роль в розумінні біології нейробластоми. Нами показано, що експресія мікроРНК-137 може бути використана в якості біомаркера для стратифікації пацієнтів за групами ризику та клінічним перебігом нейробластоми.

К л ю ч о в і с л о в а: нейробластома, експресія мікроРНК-137 
Экспрессия микроРНК-137 при нейробластоме: роль в клиническом течении и исходе заболевания.

М. В. Иномистова, Н. Н. Храновськая, О. В. Скачкова, Г. И. Климнюк, С. В. Демидов, Н. Н. Свергун

Цель. Исследовать ассоциацию экспрессии микроРНК-137 у больных с нейробластомой с клиническими и биологическими характеристиками опухоли и ее связь с выживаемостью. Методы. qRT-PCR, FISH. Результаты. Анализ уровней экспрессии микроРНК-137 в 61 образцах первично диагностированной нейробластомы показал, что у больных с известными прогностическими факторами высокого риска, таких как амплификация онкогена $M Y C N$, возраст на момент выявления заболевания, IV стадия заболевания и высокая экспрессия $M D M 2$, антагониста р53 с онкогенными свойствами, уровень экспрессии микроРНК-137 значительно снижен. Несмотря на то, что экспрессия микроРНК-137 не является независимым фактором риска, ее повышение в значительной степени связано как с улучшением безрецидивной выживаемости (5-летняя: 50,4 \% против 12,2 \%), так и с общей выживаемостью (5-летняя: 46,9 \% против 19,1 \%), что указывает на ее потенциальную роль как онкосупрессора при нейробластоме. Выводы. Мы определили, что микроРНК-137 имеет потенциально важную роль в понимании биологии нейробластомы. Нами показано, что экспрессия микроРНК-137 может быть использована в качестве биомаркера для стратификации пациентов по группам риска и клиническим течением нейробластомы.

Кл юч е в ы е с л о в а: нейробластома, экспрессия микpoРНК-137

Received 10.02.2016 